\title{
Archaeological Investigations at the Landa Park Golf Course Pro Shop, New Braunfels, Comal County, Texas
}

John W. Arnn III

Center for Archaeological Research

Follow this and additional works at: https://scholarworks.sfasu.edu/ita

Part of the American Material Culture Commons, Archaeological Anthropology Commons, Environmental Studies Commons, Other American Studies Commons, Other Arts and Humanities Commons, Other History of Art, Architecture, and Archaeology Commons, and the United States History Commons

Tell us how this article helped you.

This Article is brought to you for free and open access by the Center for Regional Heritage Research at SFA ScholarWorks. It has been accepted for inclusion in Index of Texas Archaeology: Open Access Gray Literature from the Lone Star State by an authorized editor of SFA ScholarWorks. For more information, please contact cdsscholarworks@sfasu.edu. 


\section{Archaeological Investigations at the Landa Park Golf Course Pro Shop, New Braunfels, Comal County, Texas}

\section{Creative Commons License}

\section{(c) (1) \&}

This work is licensed under a Creative Commons Attribution-NonCommercial 4.0 International License 


\title{
Archaeological Investigations at the Landa Park Golf Course Pro Shop, New Braunfels, Comal County, Texas
}

\author{
John W. Arnn, III
}

Robert J. Hard and C. Britt Bousman Principal Investigators

Texas Antiquities Committee Permit No. 1757

${ }^{\circledR}$ copyright

Center for Archaeological Research

The University of Texas at San Antonio

Archaeological Survey Report, No. 256 
The following information is provided in accordance with the General Rules of Practice and Procedure, Chapter 41.11 (Investigative Reports), Texas Antiquities Committee:

1. Type of investigation: Testing and monitoring

2. Project name: Landa Park Pro Shop

3. County: Comal

4. Principal investigators: Robert J. Hard and C. Britt Bousman

5. Name and location of sponsoring agency: City of New Braunfels; 424 S. Castell; New Braunfels, Texas 78130

6. Texas Antiquities Committee Permit No.: 1757

7. Published by the Center for Archaeological Research, The University of Texas at San Antonio, 6900 N. Loop 1604 W., San Antonio, Texas 78249-0658, 1997

A list of publications offered by the Center for Archaeological Research is available. Call (210) 458-4378; write to the Center for Archaeological Research, The University of Texas at San Antonio, $6900 \mathrm{~N}$. Loop 1604 W., San Antonio, Texas 78249-0658; e-mail to car@lonestar.utsa.edu; or visit CAR's Web site at http://www.csbs.utsa.edu/research/car/index.htm. 


\begin{abstract}
In December 1996, the Center for Archaeological Research of The University of Texas at San Antonio was contracted by the city of New Braunfels to conduct testing and monitoring to determine the impact of planned renovation on the cultural resources on the Landa Park Golf Course. The planned renovation called for extensive modifications and additions to the existing Pro Shop constructed by the WPA in the 1930s. Modifications and additions included subsurface excavations required for additional foundation footings and utility lines. Shovel testing was performed within the footprint of the proposed addition and utility trenching was monitored. Evaluation of the shovel test results called for the further excavation of a 1-x-1-m unit by CAR archaeologists.

Testing and monitoring uncovered various prehistoric and historic artifacts, including chert flakes, cores, bifaces, two projectile points (one Angostura point and another of unknown type), mussel shell, and fire-cracked rock. Historic artifacts included glass (colored and clear), one coin, aluminum pull tabs, nails, machine screws, metal fragments, one bottle cap, Bakelite fragments, and one condom wrapper.

The results of the testing and monitoring confirmed the findings of previous investigations on and adjacent to the Landa Park Golf Course which concluded that a long history of human occupation-starting from the Late Paleoindian period, through the Archaic, and into the Historic-occurred along the first terrace (T1) of the upper Comal River. However, this investigation also concluded that previous construction and landscaping, as well as erosion of the $\mathrm{T} 1$ by the Comal River, had significantly impacted the cultural remains within the project area.
\end{abstract}




\section{Contents}

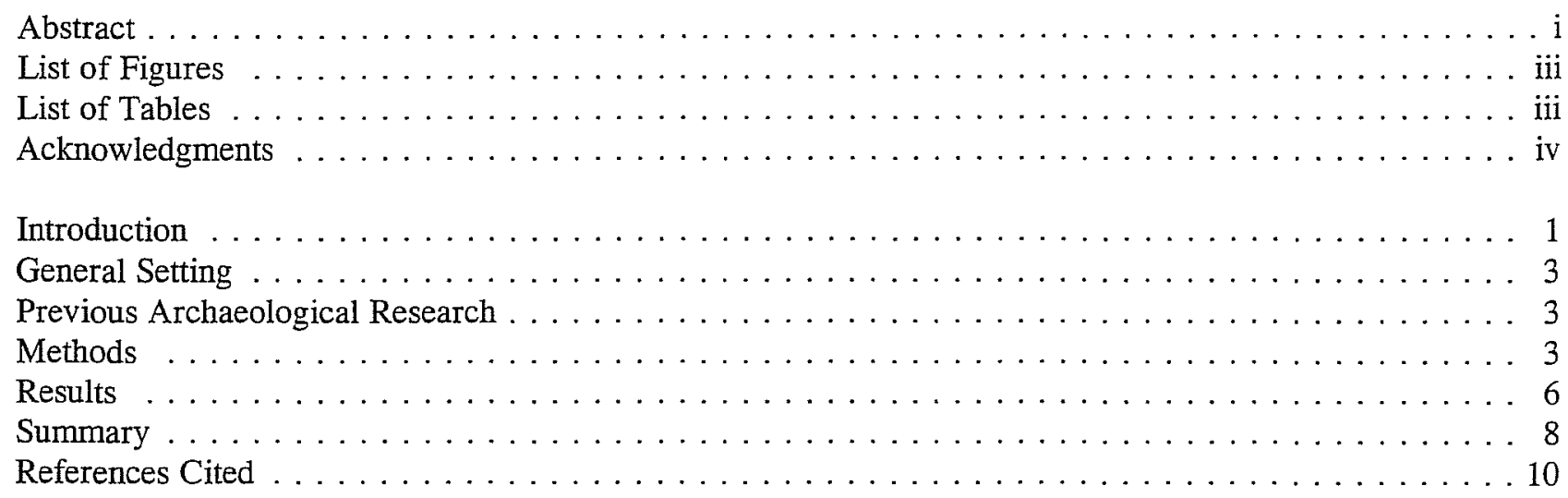




\section{Figures}

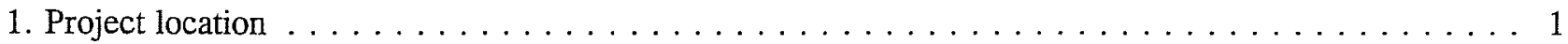

2. Location of shovel tests and excavation unit within the construction footprint $\ldots \ldots \ldots \ldots \ldots \ldots 2$

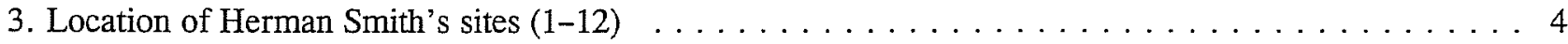

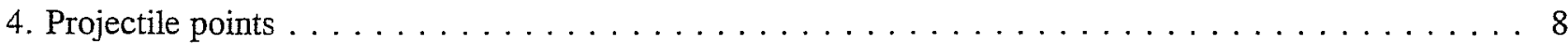

\section{Tables}

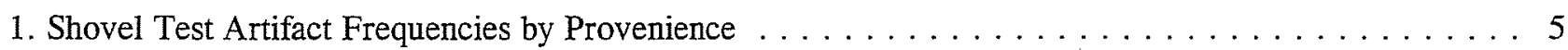

2. South Wall Profile Description of the $1-\mathrm{x}-1-\mathrm{m}$ Test Unit $\ldots \ldots \ldots \ldots \ldots \ldots \ldots \ldots \ldots \ldots \ldots \ldots \ldots \ldots \ldots$

3. Artifact Frequencies from the $1-\mathrm{x}-1-\mathrm{m}$ Excavation Unit $\ldots \ldots \ldots \ldots \ldots \ldots \ldots \ldots \ldots \ldots$ 


\section{Acknowledgments}

This project would not have been possible without the assistance and cooperation of the Landa Park golf professional Chris Acker and the Golf Advisory Board. I would also like to thank Britt Bousman for his work on the geological portion of this publication, Bruce Moses for his drafting skills, and finally Marcie Renner for her excellent editorial abilities and careful attention to detail. 


\section{Introduction}

In December 1996 the city of New Braunfels, sponsored by the Landa Park Golf Course, contracted the Center for Archaeological Research (CAR) of The University of Texas San Antonio to conduct archaeological investigations requested by the Texas Historical Commission (THC) for the Landa Park Golf Course Pro Shop expansion in New Braunfels, Texas (Figure 1). Previous testing and monitoring operations by CAR indicated the presence of artifacts and at least one intact feature in good archaeological and geological contexts, and in close proximity to the existing Landa Park Golf Course Pro Shop (Arnn 1997a). When plans were announced for the expansion of the Pro Shop, further testing in the construction area was required by the THC.

Under Texas Antiquities Committee permit number 1757, the THC requested an archaeological investigation calling for the excavation of a minimum of 10 shovel tests and a $1-x-1-m$ test unit within the footprint of the proposed expansion (Figure 2). Upon completion of the shovel tests, the $1-\mathrm{x}-1-\mathrm{m}$ test unit, and analysis of the archaeological material recovered, an interim report was written. THC and CAR then decided that foundation footings and utility line excavations should be monitored by CAR archaeologists. This report describes the methods and results of the archaeological testing and monitoring.

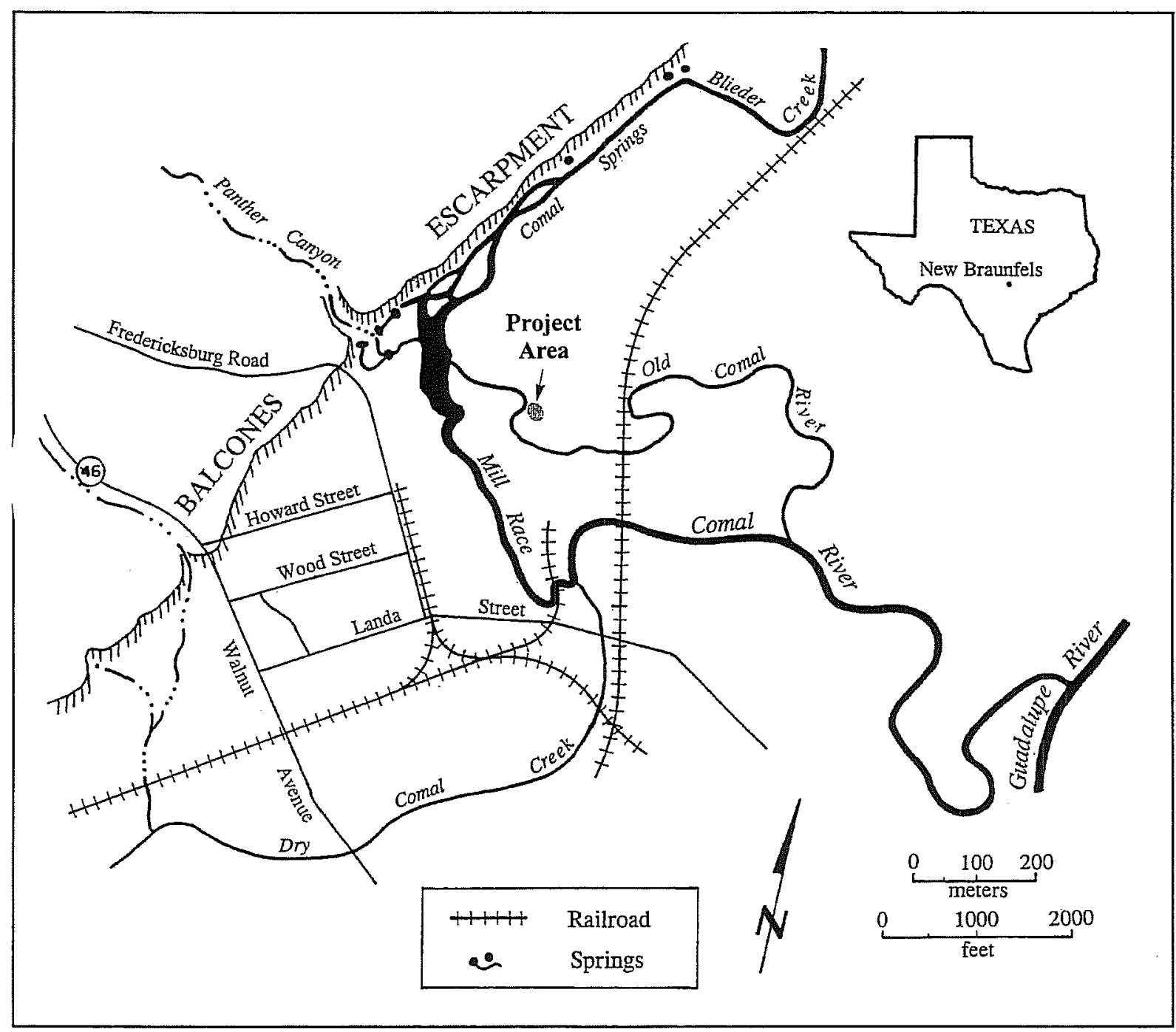

Figure 1. Project location. 


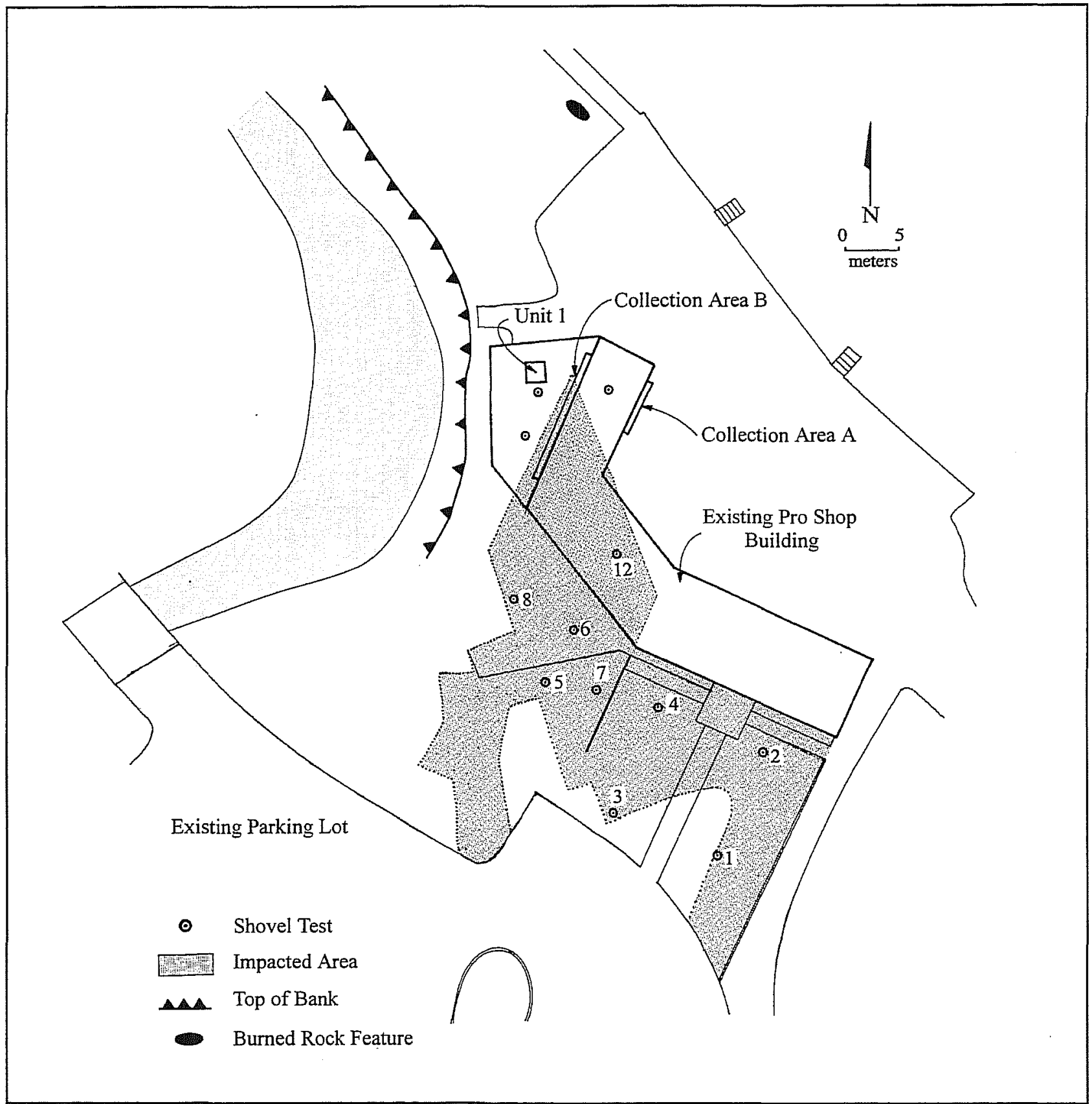

Figure 2. Location of shovel tests and excavation unit within the construction footprint, Landa Park Golf Course Pro Shop. 


\section{General Setting}

The project area is below and adjacent to the existing Pro Shop of the Landa Park Golf Course, Comal County, New Braunfels, Texas. The site is perched on the high side of a meander on the original Comal River channel, less than $300 \mathrm{~m}$ from several spring heads feeding Landa Lake. The latter was formed by the construction of a dam using slave labor in 1850 . The damming effectively pooled the flow of several large springs which result from water percolating through the Lower Cretaceous limestones of the Edwards Plateau and surfacing through fissures and cracks in the Balcones Fault at the foot of the Balcones Escarpment (Bailey and Bousman 1989:7).

The escarpment marks the convergence of the Blackland Prairie, consisting of bush and short grasses, and the Mesquite Chaparral Savanna, consisting of small trees, shrubs, and cacti (Bailey 1986:4). The transitional nature of the escarpment combined with abundant water resources and a wide range of plant and animal species has presented a favorable environment for human occupation during both prehistoric and historic times. Previous archaeological investigations in the project area and at other nearby major springs along the Balcones Escarpment demonstrated that archaeological materials are particularly rich and widely distributed, and span virtually the entire record of human occupation in North America (Armn 1997a, 1997b, 1997c; Bailey 1986; Bailey and Bousman 1989; Ricklis et al. 1991; Shiner 1983; Smith 1985; Takac et al. 1992). According to an 1868 map of New Braunfels, the area known today as the Landa Park Golf Course was used by early European settlers as pasture land (Bailey and Bousman 1989:11). Since that time, development of the project area has been limited to relatively minor subsurface impacts involved in golf course landscaping.

\section{Previous Archaeological Research}

Previous archaeological investigations were conducted on the golf course by Herman Smith in 1984 (Smith 1985), Mark Denton in 1986 and 1987 (Denton 1986, 1987), and John Arnn in 1996 and 1997 (Arnn 1997a). Smith conducted a pedestrian survey primarily along the water courses of Landa Park and the golf course. Smith reported 12 sites to the THC (Figure 3 ), seven of which (site numbers 5 , $6,7,8,9,10$, and 11) were located on the golf course, with three adjacent to the current project area (Smith 1985). Denton recorded Smith's site number 5 as 41CM175 with the Texas Historical Commission in 1987 (Denton 1987). Smith and Denton both reported chert flakes and debitage and recommended monitoring future development in the area.

Archaeological investigations conducted by CAR on the first terrace of Landa Lake in 1996 revealed the presence of widespread and abundant cultural materials dating from Late Paleoindian to Late Archaic (Arnn 1997a, 1997b). Also included in the results of those investigations was the discovery of an intact burned rock feature with lithic artifacts less than $10 \mathrm{~m}$ from the Pro Shop project area (Arnn 1997a).

\section{Methods}

\section{Shovel Testing}

Based on the blueprints for the Pro Shop expansion, 10 shovel tests (ST) were excavated initially (Figure 2 ) in 10-cm levels to varying depths. Two additional shovel tests (STs 11 and 12) were excavated during monitoring of the foundation footing excavations and are discussed in greater detail below (see Monitoring). The depth of individual shovel tests was determined by the amount of artifacts encountered (if no artifacts were encountered, the excavation was halted) and the difficulty of excavation (if bedrock or some other impenetrable object was encountered, excavation was halted). The maximum shovel test depth was $80 \mathrm{~cm}$ and the minimum was $45 \mathrm{~cm}$. 
This page has been

redacted because it

contains restricted

information. 
Table 1. Shovel Test Artifact Frequencies by Provenience

\begin{tabular}{|c|c|c|c|c|c|c|c|c|c|c|c|c|}
\hline $\begin{array}{c}\text { Depth } \\
\text { (cm) }\end{array}$ & ST 1 & ST 2 & ST 3 & ST 4 & ST 5 & ST 6 & ST 7 & ST 8 & ST 9 & ST 10 & ST 11 & ST 12 \\
\hline $0-10$ & $\begin{array}{l}1 \text { pull } \\
\text { tab }\end{array}$ & $\begin{array}{l}3 \text { hist. } \\
1 \mathrm{flk}\end{array}$ & & $\begin{array}{l}2 \text { hist. } \\
2 \text { flks }\end{array}$ & $\begin{array}{c}26 \mathrm{flks} \\
1 \mathrm{FCR}\end{array}$ & $\begin{array}{l}1 \text { hist. } \\
3 \text { flks }\end{array}$ & $\begin{array}{l}3 \text { hist. } \\
2 \text { flks }\end{array}$ & $\begin{array}{l}4 \mathrm{flks} \\
1 \mathrm{MS}\end{array}$ & $\begin{array}{l}6 \text { flks } \\
1 \text { hist. }\end{array}$ & $10 \mathrm{flks}$ & $\begin{array}{l}22 \mathrm{flks} \\
3 \mathrm{FCR}\end{array}$ & $\begin{array}{l}16 \text { flks } \\
1 \text { FCR } \\
5 \text { glass }\end{array}$ \\
\hline $10-20$ & 5 flks & $\begin{array}{l}3 \text { hist. } \\
4 \text { flks }\end{array}$ & 17 flks & $7 \mathrm{flks}$ & 15 flks & $\begin{array}{l}12 \text { flks } \\
1 \text { hist. }\end{array}$ & $8 \mathrm{flks}$ & $\begin{array}{l}1 \text { hist. } \\
10 \text { flks }\end{array}$ & $\begin{array}{l}1 \text { hist. } \\
5 \text { flks }\end{array}$ & $19 \mathrm{flks}$ & $\begin{array}{l}22 \mathrm{flks} \\
4 \mathrm{FCR}\end{array}$ & $\begin{array}{l}2 \mathrm{FCR} \\
1 \text { glass }\end{array}$ \\
\hline $20-30$ & 2 flks & $1 \mathrm{flk}$ & $\begin{array}{l}4 \text { hist. } \\
6 \text { flks }\end{array}$ & & $2 \mathrm{flks}$ & $\begin{array}{c}21 \text { flks } \\
2 \text { hist. }\end{array}$ & $3 \mathrm{flks}$ & $15 \mathrm{flks}$ & $1 \mathrm{flk}$ & $9 \mathrm{flks}$ & $5 \mathrm{flks}$ & $5 \mathrm{flks}$ \\
\hline $30-40$ & 5 flks & $\begin{array}{c}9 \mathrm{flks} \\
1 \mathrm{MS}\end{array}$ & $7 \mathrm{flks}$ & & $4 \mathrm{flks}$ & $19 \mathrm{flks}$ & $4 \mathrm{flks}$ & $8 \mathrm{flks}$ & $8 \mathrm{flks}$ & $17 \mathrm{flks}$ & $4 \mathrm{flks}$ & $1 \mathrm{flk}$ \\
\hline $40-50$ & 4 flks & $2 \mathrm{flks}$ & $\begin{array}{c}19 \mathrm{flks} \\
1 \mathrm{MS}\end{array}$ & & & $8 \mathrm{flks}$ & & & $8 \mathrm{flks}$ & $\begin{array}{l}11 \mathrm{flks} \\
1 \mathrm{FCR}\end{array}$ & & $2 \mathrm{flks}$ \\
\hline $50-60$ & $\begin{array}{l}2 \text { hist. } \\
1 \text { flks }\end{array}$ & $1 \mathrm{flk}$ & $11 \mathrm{flks}$ & & & 3 flks & & & & $6 \mathrm{flks}$ & & \\
\hline $60-70$ & & & $\begin{array}{c}11 \mathrm{flks} \\
2 \mathrm{MS}\end{array}$ & & & & & & & & & \\
\hline $70-80$ & & & 4 flks & & & & & & & & & \\
\hline
\end{tabular}

Key to abbreviations: flk - flake FCR - fire-cracked rock hist. - historic MS - mussel shell 
Table 2. South Wall Profile Description of the 1-x-1-m Test Unit

\begin{tabular}{|c|c|c|}
\hline Zone & Depth & Description \\
\hline 1 & $0-0.2$ & $\begin{array}{l}\text { Light yellowish-brown (10YR 6/4) to brown (10YR 4/3) silt loam, alternating thin }(0.5-1 \mathrm{~mm} \text { ) } \\
\text { layers, upper surface is mud-cracked, all boundaries are very abrupt, Ap1 horizon. }\end{array}$ \\
\hline 2 & $0.2-0.5$ & $\begin{array}{l}\text { White (10YR 8/2) calcium carbonate small nodules and films that form a crust, very abrupt and } \\
\text { smooth lower boundary, Ap2 horizon. }\end{array}$ \\
\hline 3 & $0.5-2$ & $\begin{array}{l}\text { Dark brown (10YR 3/3) friable loam, thin fine platy structure resulting from compaction, very } \\
\text { abrupt smooth lower boundary, Ap3 horizon. }\end{array}$ \\
\hline 4 & $2-20$ & $\begin{array}{l}\text { Dark brown (10YR 3/3) friable loam, weak fine-medium sub-angular blocky structure, common } \\
\mathrm{CaCO}_{3} \text { flecks and films, few small fragmented snail shells, few flakes, few small }(1-3 \mathrm{~cm}) \text { stream } \\
\text { worn pebbles, clear smooth lower boundary, } \mathrm{A} 1 \text { horizon. }\end{array}$ \\
\hline 5 & $20-35$ & $\begin{array}{l}\text { Dark yellowish-brown (10YR 3/4) friable loam, weak fine-mediumsub-angular blocky structure, } \\
\text { increased frequency of } \mathrm{CaCO}_{3} \text { films on ped faces, few roots, abrupt smooth lower boundary, A2 } \\
\text { horizon. }\end{array}$ \\
\hline 6 & $35-45$ & $\begin{array}{l}\text { Dark yellowish-brown (10YR 4/4) firm clay loam, moderate medium sub-angular blocky } \\
\text { structure, few } \mathrm{CaCO}_{3} \text { films on ped faces, rare small manganese nodules and stains on ped faces, } \\
\text { few roots, few fragmented snail shells, clear smooth lower boundary, Bwk1 horizon. }\end{array}$ \\
\hline 7 & $45-65$ & $\begin{array}{l}\text { Dark brown ( } 7.5 \text { YR } 3 / 4) \text { to yellowish-brown (10YR 5/6) firm mottled clay loam, few } \mathrm{CaCO}_{3} \\
\text { small nodules that increase in frequency down profile, few small broken snail shells, gradual } \\
\text { smooth lower boundary, Bwk2 horizon. }\end{array}$ \\
\hline 8 & $65-80$ & $\begin{array}{l}\text { Dark yellowish brown (10YR 4.5/6) very firm clay loam, moderate medium angular blocky } \\
\text { structure with incipient slickensides, few small }(1-4 \mathrm{~cm}) \text { stream rolled pebles, increased number } \\
\text { of } \mathrm{CaCO}_{3} \text { nodules compared to overlying zone, clear smooth lower boundary, Bwk3 horizon. }\end{array}$ \\
\hline 9 & $80-110$ & $\begin{array}{l}\text { Strong brown ( } 7.5 \mathrm{YR} 4 / 6) \text { very firm clay loam, moderate medium angular blocky structure with } \\
\text { slickensides, common }(5 \%) \mathrm{CaCO}_{3} \text { nodules, manganese films on ped faces, clear smooth lower } \\
\text { boundary, Bwk4 horizon. }\end{array}$ \\
\hline 10 & $110-120+$ & $\begin{array}{l}\text { Strong brown }(7.5 \mathrm{YR} 4 / 5) \text { very firm clay loam, moderatefine-medium angular blocky structure, } \\
\text { common }(10 \%) \mathrm{CaCO}_{3} \text { nodules that are larger than above zones, lower boundary not observed, } \\
\text { Bwk5 horizon. }\end{array}$ \\
\hline
\end{tabular}

foundation footings. Artifacts were collected and their general locations recorded. Two additional shovel tests were excavated (STs 11 and 12) to determine whether cultural features or materials had been covered by the original foundation slab. These shovel tests were excavated to culturally sterile depths.

\section{Utility Trenching}

One utility trench was excavated extending from the Pro Shop northeast to Elizabeth Avenue. The trench was excavated with a motorized ditch witch to a depth of $45 \mathrm{~cm}$. The trench measured approximately $20-25 \mathrm{~cm}$ wide by $295 \mathrm{~m}$ long. The trench was monitored as it was being excavated. After trenching was completed, the first meter in every five meters of backdirt was raked and examined for artifacts.

\section{Results}

\section{Shovel Testing}

Various artifacts, ranging from historic to prehistoric, were encountered during shovel testing (Table 1). The historic artifacts included glass (colored and clear), one coin, aluminum pull tabs, machine screws, metal fragments, Bakelite fragments, one 
bottle cap, and one condom wrapper. Prehistoric artifacts included chert flakes, mussel shell, and a small amount of fire-cracked rock. The highest artifact frequencies occurred in ST $3(n=79)$, which was also the deepest shovel test at $80 \mathrm{~cm}$. The lowest frequencies occurred in ST $4(n=11)$ which was also the shallowest shovel test (Table 1). Historic artifacts occurred as deep as $60 \mathrm{~cm}$ in ST 1, but the majority of historic artifacts occurred between $0-20 \mathrm{~cm}$. This overall pattern of artifact frequency and provenience may be indicative of highly disturbed deposition as discussed below.

\section{1-x-1-m Test Unit}

Both historic and prehistoric artifacts were encountered in the test unit (Table 3 ). The profile description (see Table 2) indicates that a thin portion of the upper sediments are disturbed and compacted $(0-2 \mathrm{~cm})$. Below this are in situ sediments with a subdivided A-horizon between 2-35 cm and a subdivided Bwk-horizon ( $B$ horizons with calcium carbonated precipitants and reddish weathering) between $35-120 \mathrm{~cm}$.
Historic artifacts were only encountered in the first level $(0-10 \mathrm{~cm})$. These included a roofing nail, a common round nail, a metal spring, and one piece of Bakelite.

Prehistoric artifacts included chert flakes, mussel shell, and four bifaces, but no temporally diagnostic artifacts. Prehistoric artifacts were encountered in all levels down to $110 \mathrm{~cm}$, but the bottom level $(110-120 \mathrm{~cm})$ was sterile.

The flake count peaked between 20 and $30 \mathrm{~cm}$ and began to drop off drastically below $40 \mathrm{~cm}$. Most of the artifacts were recovered in A-horizon sediments and the artifact frequencies were considerably lower in the underlying $\mathrm{B}$-horizons.

\section{Utility Trenching}

Trenching exposed seven lithic (chert) artifacts widely scattered across $295 \mathrm{~m}$. All artifacts were prehistoric and consisted of three flakes, a core fragment, two biface fragments, and one projectile point (Figure 4a). The point does not represent any previously recorded type in Texas, although a similar projectile point was recently found in San Marcos (Cargill and Brown 1997:11, Figure 5d).

Table 3. Artifact Frequencies from the 1-x-1-m Excavation Unit

\begin{tabular}{||c|c|c|c|c|l||}
\hline $\begin{array}{c}\text { Depth } \\
\text { (cm) }\end{array}$ & Flakes & Bifaces & $\begin{array}{c}\text { Fire-cracked } \\
\text { Rock }\end{array}$ & $\begin{array}{c}\text { Mussel } \\
\text { Shell }\end{array}$ & Historic \\
\hline $0-10$ & 23 & 0 & 0 & 0 & 1 roof nail, 1 common nail, 1 spring, 1 bakelite frag. \\
\hline $10-20$ & 124 & 1 & 1 & 0 & \\
\hline $20-30$ & 244 & 0 & 1 & 3 & \\
\hline $30-40$ & 219 & 2 & 4 & 4 & \\
\hline $40-50$ & 50 & 1 & 3 & 1 & \\
\hline $50-60$ & 12 & & & 2 & \\
\hline $60-70$ & 16 & & & 6 & \\
\hline $70-80$ & 22 & & & 3 & \\
\hline $80-90$ & 8 & & & 4 & \\
\hline $90-100$ & 4 & & & 1 & \\
\hline $100-110$ & 2 & & & & \\
\hline $110-120$ & & & & & \\
\hline
\end{tabular}




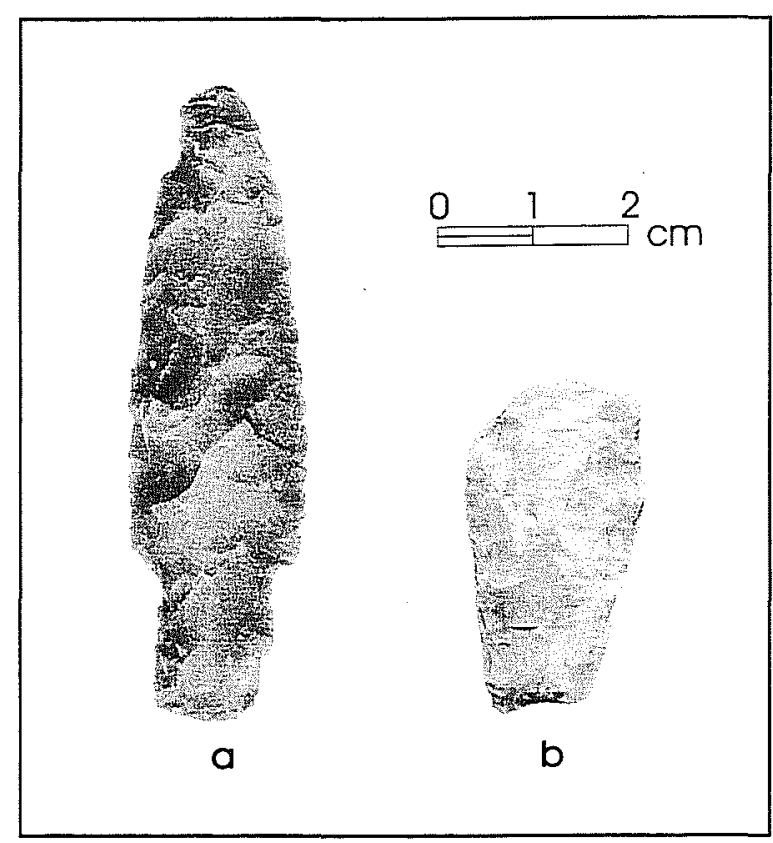

Figure 4. Projectile points. a. unknown type; b. reworked Angostura

\section{Monitoring}

Monitoring of the slab removal exposed two areas of lithic scatter, Collection Area A and Collection Area $\mathrm{B}$, directly beneath the existing slab. Collection Area A contained eight flakes and one core fragment, all made of chert. Collection Area B contained 33 flakes, three core fragments, three pieces of firecracked rock, and one reworked Angostura projectile point (Figure 4b).

\section{Summary}

Historic and prehistoric artifacts do occur within the footprint of the proposed Golf Pro Shop expansion. However, artifact frequency as well as the ratio of prehistoric to historic artifacts varies widely throughout the project area. Furthermore, no diagnostic projectile points, tools, or features were found in good provenience and only fragments of bifaces and flakes to indicate any tool production.

The results of the shovel tests revealed the greatest disparity between provenience and artifact frequencies. ST 3 had the highest artifact frequency at 79. But ST 4, which was in close proximity to ST 3 , had the lowest at 11. ST 1 had historic material to a depth of at least $50+\mathrm{cm}$ but, the majority of shovel tests had no historic material beyond $20 \mathrm{~cm}$. A conversation with the golf professional and head groundskeeper revealed that a large amount of fill was placed directly in front of the Pro Shop between 1969 and 1972. The area they indicated was well within the expansion footprint and included ST 1-4 and ST 7 (Figure 2). This helps explain the inconsistent artifact frequencies as well as the seemingly random location of historic material (Table 1).

ST 5 appears to reflect a pattern of artifact deposition consistent with good archaeological and geological contexts (Table 1). ST 6, the closest shovel test to ST 5 , is located on an artificially constructed terrace approximately $30-40 \mathrm{~cm}$ above ST 5. An examination of ST 6 based on the depth of artifact frequencies and with a subtraction of $30-40 \mathrm{~cm}$ from the surface (to account for the elevation of the terrace) reveals a vertical frequency similar to ST 5 (Table 1). This same pattern can also be seen, albeit to a lesser extent, in ST 8 which is located on the same terrace (Table 1 and Figure 2). In short, due to the natural slope of the terrace and recent landscaping, some shovel tests appear to reflect different proveniences for artifact frequencies. In reality, the cultural lens of some shovel tests do correspond well with each other. A comparison of the $0-10 \mathrm{~cm}$ level in ST 5 to level $20-30 \mathrm{~cm}$ in ST 6 is a good example, as is, to a lesser extent, the level $20-30 \mathrm{~cm}$ in ST 8 with the above-mentioned levels for ST 5 and ST 6.

Only two projectile points were recovered during this investigation. One projectile point has defied typology and therefore remains nondiagnostic. However, the discovery of a similar point at Crook's Park in San Marcos suggests that it could eventually be classified into a well defined type (Cargill and Brown 1997:11, Figure 5d). The other point was typed as an Angostura and showed signs of being reworked. The provenience of the Angostura projectile point found in Collection Area B is highly questionable for several reasons. The excavation technique used to recover the artifacts involved a backhoe and there is no way to ascertain whether the 
point was transported with construction fill prior to the pouring of the slab or by the hands of Native Americans. Furthermore, the fact that it was reworked suggests the possibility that it could have been picked up, reworked, reused, and transported, who knows how far, perhaps several thousand years after its initial manufacture. Finally, the artifact frequencies in both Collection Area A and Collection Area B may suggest that a cultural level was disturbed and at least partially removed when the original foundation slab was excavated.

The 1-x-1-m excavation unit appears to be in good archaeological and geological context. The unit itself lies less than four meters from the present-day bank of the Comal River, represents the top of the $\mathrm{T} 1$ terrace, and is within $20 \mathrm{~m}$ of the burned rock feature identified in previous archaeological investigations (Arnn 1997a). The artifact frequencies indicate a concentration of cultural materials between 10 and 40 $\mathrm{cm}$ below the surface. The majority of recovered cultural material was chert flakes, with minuscule amounts of fire-cracked rock and mussel shell.

Despite the close proximity to the previously identified burned rock feature, there was no evidence to suggest the presence of in situ features beyond that of cultural lenses in the project area. In terms of real, present-day elevations the surface elevation of ST 5 is one meter below the surface elevation for the $1-\mathrm{x}-1-\mathrm{m}$ excavation unit. With this in mind, the deposition pattern identified in ST 5 corresponds approximately to level $70-80$ and below in the 1-x-1$\mathrm{m}$ excavation unit. This corresponding pattern, when compared to the other shovel tests, reflects marked subsurface disturbance which probably reflects natural erosion and the original WPA construction of the Golf Pro Shop in the 1930s. The bulk of cultural material also appears to be concentrated at, or near, the waters edge as is borne out by the results of the trenching operations. Finally, it is possible that at least some portion of this site has eroded into the steeply cut bank of the Comal River. This is consistent with Herman Smith's report (Smith 1985) Based on the evidence from this investigation, as well as previous studies the construction necessary for the Pro Shop expansion will not seriously impact subsurface archaeological deposits. However, we recommend that future development be monitored by archaeologists and recommend that the boundaries of $41 \mathrm{CM} 175$ be expanded to include the T1 terrace. 


\section{References Cited}

Arnn, J. W., III

1997a Archaeological Investigations at the Landa Park Golf Course, New Braunfels, Texas. Archaeological Survey Report, No. 250. Center for Archaeological Research, The University of Texas at San Antonio.

1997b Archaeological Monitoring of a Sidewalk Construction Project in Landa Park, New Braunfels, Comal County, Texas. Archaeological Survey Report, No. 254. Center for Archaeological Research, The University of Texas at San Antonio.

1997c Archaeological Monitoring of a Parking Lot Construction Project in New Braunfels, Comal County, Texas. Archaeological Survey Report, No. 255. Center for Archaeological Research, The University of Texas at San Antonio.

Bailey, G. L.

1986 Archaeological Investigations in Landa Park, City of New Braunfels, Comal County, Texas. Letter Report No. 330. Prewitt, Austin.

Bailey, G. L., and C. B. Bousman

1989 Subsurface Archaeological Survey and Monitoring of the Landa Street/Fredericksburg Road Drainage Improvement Project, Comal County, Texas. Technical Reports No. 6. Prewitt, Austin.

Batte, C. D.

1984 Soil Survey of Comal and Hays Counties, Texas. Soil Conservation Service, United States Department of Agriculture, Washington, D.C.

Cargill, D. A., and M. Brown

1997 Archaeological Testing at Crook's Park in San Marcos, Hays County, Texas. Archaeological Survey Report, No. 263. Center for Archaeological Research, The University of Texas at San Antonio.

Denton, $\mathrm{M}$.

1986 Field notes, 41CM76. On file, Texas Historic Commission, Austin.

1987 Field notes, 41CM75. On file, Texas Historic Commission, Austin.

Ricklis, R. A., M. D. Blum, and M. B. Collins

1991 Archeological Testing at the Vera Daniel Site (41TV1364), Zilker Park, Austin, Texas. Studies in Archeology 12. Texas Archeological Research Laboratory, The University of Texas at Austin.

Shiner, J. L.

1983 Large Springs and Early American Indians. Plains Anthropologist 28:1-7.

Smith, $\mathrm{H}$.

1985 An Assessment of Archaeological Resources in Landa and Cypress Bend Recreation Areas, New Braunfels, Texas. Manuscript on file. Texas Historical Commission, Austin. 
Takac, P. R., P. Goldberg, and S. Valastro

1992 Archeological and Geomorphological Testing Along the Proposed South Austin Outfall Relief Main, Phase II Tunnel Alignment: The Vara Daniel Site (41TV1364), Zilker Park, Austin Texas. Technical Series 28. Texas Archeological Research Laboratory, The University of Texas at Austin.

Turner, E. S., and T. R. Hester

1993 A Field Guide to Stone Artifacts of Texas Indians. Second edition. Gulf, Houston. 


